\title{
Laparoscopic Adhesiolysis in Acute Mechanical Intestinal Obstruction Due to Adhesion
}

\author{
(ㄷ) Mehmet Mustafa Altıntaş, (오 Selçuk Kaya
}

Departman of General Surgery, Kartal Dr. Lütfi Kırdar City Hospital, Istanbul, Turkey

Submitted: 11.11.2020 Accepted: 09.12.2020

Correspondence: Selçuk Kaya Kartal Dr. Lütfi Kırdar Şehi Hastanesi, Genel Cerrahi Anabilim Dalı, İstanbul, Turkey E-mail: selcukkaya_36@hotmail.com

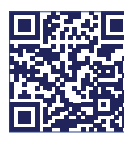

Keywords: Adhesion; laparoscopic adhesiolysis; mechanical intestinal obstruction.

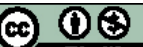

This work is licensed under a Creative Commons tribution-NonCommercial 4 International License.

\begin{abstract}
Objective: The aim of the study was to discuss our clinical experience of laparoscopic adhesiolysis in acute mechanical bowel obstruction (MBO) due to post-operative adhesion in the light of the literature.
\end{abstract}

Methods: Patients who underwent laparoscopic adhesiolysis due to acute MBO due to adhesion between January 2014 and December 2019 were included in the study. Diagnosis of acute MIO was put with patient's history, clinical examination findings, standing direct abdominal radiography, and computed tomography. Laparoscopic adhesyolysis was applied to those who did not respond to conservative treatment at the end of $24-48 \mathrm{~h}$.

Results: Twenty-four patients with laparoscopic adhesiolysis were included in the study. Sixteen of the patients were women and eight were men. The average age was 52 years (27-74). Post-operative MBO due to adhesion and dilatation in the proximal of the adhesion was observed in the distal ileum in 14 patients, in the proximal jejunum in ten patients. For 4 (16.7\%) patients, it was switched to open surgery due to technical difficulties. Douglas drain was placed in seven of the patients to monitor the risk of possible bleeding and intestinal perforation. Oral intake was started in patients whose abdominal pain and nausea complaints regressed on the Ist post-operative day. Patients were discharged after an average post-operative 4.2 (2-8) days. Loop ileostomy was performed in one patient, when intestinal contents came from the drain on the post-operative on the $3^{\text {rd }}$ day. Post-operative mortality was not observed in any of our patients.

Conclusion: In light of the increasing use of laparoscopic surgery in recent years, due to the disadvantages of the conventional surgical method in acute MBO due to post-operative adhesion, we believe that the laparoscopic approach will safely become widespread.

\section{INTRODUCTION}

Intra-abdominal adhesions secondary to abdominal operations remain major problem and is associated with many pathological conditions such as chronic abdominal pain, ventral hernia, intestinal motility disorders, infertility, and dyspareunia, especially acute mechanical bowel obstruction (MBO). ${ }^{[1,2]}$ The most frequent surgical morbidity caused by intra-abdominal adhesions is MBO. In Western countries, the most common cause of $\mathrm{MBO}$ is post-operative intra-abdominal adhesions. ${ }^{[3]}$ Adhesion occurs in $50-70 \%$ of patients received abdominal surgeries. However, only 20$30 \%$ of them are presented with clinical symptoms. ${ }^{[4,5]}$ After numerous previous abdominal surgeries, the incidence of intra-abdominal adhesions can reach up to $93 \%{ }^{\left[{ }^{[6]}\right.}$

According to some authors, appendectomy and gynecological operations are blamed for majority of post-oper- ative adhesions, while colorectal surgery remains in the second rank. ${ }^{[4,5]}$ Omentum, small intestines, anterior abdominal wall, and gynecological organs are most frequent localizations for post-operative intra-abdominal adhesions. However, small intestine, especially ileum, plays major role for $M B O .^{[7]}$

Plain abdominal graphies may reveal up to $60 \%$ exact diagnosis in the light of good history and clinical examination. However, in recent years, advanced imaging techniques such as magnetic resonance imaging (MRI) and computed tomography (CT) have been recommended as appropriate noninvasive tools for the evaluation of intra-abdominal adhesions. ${ }^{[8,9]}$

Majority of patients suffering from MBO, due to postoperative adhesion, may benefit from conservative treatment; however, there is still a group that requires surgical intervention. ${ }^{[10,11]}$ Laparotomy was our surgical choice un- 
til recently, to deal with $\mathrm{MBO}$ due to adhesion. However, open surgery is associated with new adhesion formation, development of abdominal wall hernia, increased postoperative pain, and ileus development. ${ }^{[1,12]}$ Laparoscopic surgery was previously considered as contraindicated in MBO due to adhesion. However, with increasing experience, this minimally invasive method has become a point of interest for surgeons in the treatment of post-operative adhesive disease, due to less tissue trauma, less intra-abdominal adhesion, less risk of ventral hernia, etc. ${ }^{[13,14]}$

In this study, our aim is to discuss our clinical experience of laparoscopic adhesiolysis in acute MBO due to post-operative adhesion in the light of the literature.

\section{MATERIALS AND METHODS}

Patients who underwent laparoscopic adhesiolysis between January 2014 and December 2019 were included in the study. Informed consent was obtained from all patients regarding laparoscopic surgery, possible transition to open surgery, and possible complications. Approval was obtained from the Ethics Committee of our hospital $(2020 / 514 / 187 / 3)$ for this study.

\section{Algorithm}

Acute MBO was diagnosed with the patient's history, clinical examination findings, and abdominal graphies. The diagnosis of acute MBO was confirmed by abdominal CT, and tumors and other intra-abdominal pathologies were also ruled out (Fig. I). Only patients who developed acute MBO due to post-operative adhesion were included in the study. Cases suffering from tumor, Crohn's disease, and radiation enteritis were excluded from the study. These patients were observed primarily by conservative treatment for 24-48 h. Nasogastric decompression, cessation of oral
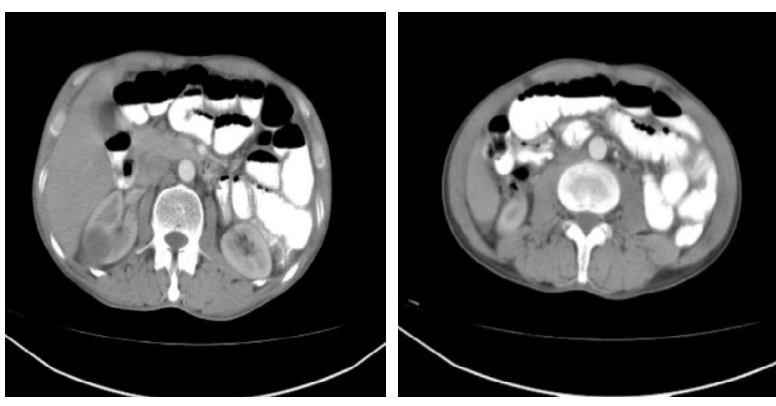

Figure 1. CT images with acute MBO due to postoperative adhesion.
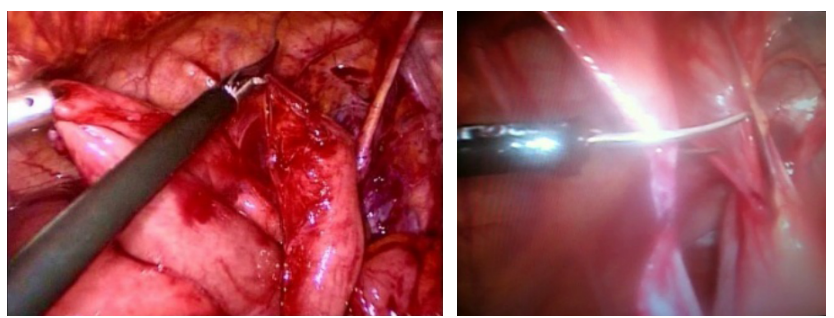
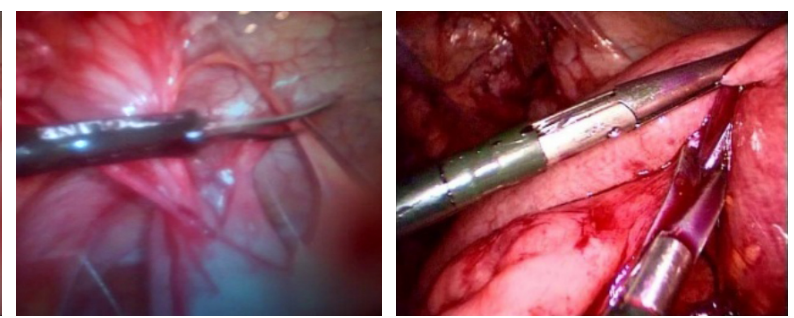

intake, fluid-electrolyte support, and antibiotherapy were applied. The presence of obstruction findings and symptoms remains major obstacle for conservative treatment and those cases were prepared for laparoscopic adhesiolysis after $48 \mathrm{~h}$.

\section{Surgical technique}

Under general anesthesia, all patients were positioned in the supine position, with both arms open, surgeon standing on the left side of the patient and laparoscopy system on the right side. Later, a $10 \mathrm{~mm}$ throcar was placed under open vision in the left upper quadrant, assuming no adhesion, through help of nasogastric decompression by inserting a Foley catheter. Pneumoperitoneum was set to be a maximum of $14 \mathrm{mmHg}$. Then, with the help of a $30^{\circ}$ camera, two more trocars of $5 \mathrm{~mm}$ from the left lower quadrant were placed in the abdomen at the level of the umbilicus, in the left anterior axillary line. Additional trocar was inserted if necessary, depending on the technical difficulty or localization of the adhesion. Adhesions in anterior abdominal wall were separated in the first place. Abdominal space was explored using atraumatic bowel clamps. Especially distended and dilated bowel loops were observed and pathological birds were detected. Adhesiolysis was applied through sharp dissection, in case of bleeding risk, an energy source was utilized. Normal intestinal color and peristalsis, reflecting viable intestine remain end points for our surgical success. Depending on surgeon's preference, the operation was terminated by placing a drain in the lower abdominal quadrant through the trocar entrance in the left lower quadrant (Fig. 2).

In the post-operative period, depending on absence of abdominal pain and regression of nausea complaints, oral liquid food was started on the Ist post-operative day.

\section{Statistical analysis}

The study data were evaluated using descriptive statistical methods (mean standard deviation) and "Student's t-test" in comparison of the data showing normal distribution between groups.

\section{RESULTS}

Twenty-four patients scheduled for laparoscopic adhesiolysis between January 2014 and December 2019 were included in the study ( 16 females and eight males). Mean age was 52 years (27-74). Acute MBO due to post-oper-

Figure 2. Laparoscopic adhesiolysis operation sections. 
ative adhesion was seen in the distal ileum in 14 patients, in the proximal jejunum in ten patients. Four (16.7\%) patients received conversion to open surgery due to technical difficulties. Circulatory impairment was observed in six patients. Intestinal color and peristalsis returned to normal in all patients following adhesiolysis. Douglas drain was placed in seven of the patients to monitor the risk of possible bleeding and intestinal perforation. Oral intake was started in patients whose abdominal pain and nausea complaints regressed, on the Ist post-operative day. Requirement of pain killers decreased dramatically in the post-operative period. Patients were discharged after an average post-operative $4.2(2-8)$ days. In a single patient suffering from intestinal fluid in the drain bag, second operation was needed on the 3rd post-operative day. An ileostomy was created for controlling of perforated segment. The patient, whose ostomy was actively working on the 4th post-operative day, was discharged. There was no mortality in any of our patients.

\section{DISCUSSION}

The diagnosis of acute MBO due to post-operative adhesion is made by history taking, physical examination, and imaging methods. In $60 \%$ of cases abdominal graphies may be sufficient. However, in recent years, advanced imaging methods such as MRI and CT have been recommended to rule out other abdominal pathologies and to evaluate intra-abdominal adhesions. ${ }^{[8,9]}$ We also utilized abdominal graphies and CT in our study.

Laparotomy was the only method in the surgical treatment of acute MBO due to adhesion until recently. Laparoscopic surgery was previously considered as contraindicated in MBO due to adhesion. However, with increasing experience, this minimally invasive method has become a point of interest for surgeons in the treatment of postoperative adhesive disease, due to less tissue trauma, less intra-abdominal adhesion, and less risk of ventral hernia. Laparoscopic adhesiolysis is currently being performed in many centers as a result of increased experience in laparoscopic surgery, and its results have been shown to be similar or superior to open surgery. ${ }^{[12]}$

In laparoscopic approach, there is not a single definitive algorithm, and there is still no common consensus regarding the patient selection strategy, technical details, and the extent of adhesiolysis. In some publications, they suggest complete adhesiolysis from the ileocecal valve to the ligamentum of Treitz. ${ }^{[5,16]}$ Disadvantage of this method is that it may cause recurrent adhesions as well as causing innocent adhesions to become pathological. Therefore, limited adhesiolysis remains as current approach in the light of definitive and exact localizations of adhesions.

All cases, in our study, were patients who developed acute MBO in the post-operative period. We applied limited adhesiolysis to all our patients. For selective adhesiolysis, the location of the pathological adhesion must be determined. While defining the location of pathological adhesion in our patients perioperatively, we took the intestinal segment where dilatation ended as the cue point. In many studies, it has been reported that this cue point is used in the detection of pathological adhesion. ${ }^{[17,18]}$

Another debate in laparoscopic adhesiolysis is the placement technique and location of the first trocar. It is obvious that these patients have intra-abdominal adhesions. Intestinal injuries related to the first trocar insertion have been reported in the literature. ${ }^{[19]}$ Some authors, with the idea that there will be no adhesion in the left upper quadrant, suggest that a trocar be placed blindly after the insufflation of the abdomen with the help of a Veress needle 2 $\mathrm{cm}$ below the midclavicular or even rib arch. ${ }^{[16,20]}$ However, it is known that there may be adhesions in the left upper quadrant even if the patient has undergone lower abdominal or pelvic surgery. ${ }^{[14]}$ Yuvaci et al. ${ }^{[2]}$ reported the sensitivity of transabdominal ultrasonography as $96.39 \%$ and specificity as $\mathbf{9 7 . 4 3 \%}$ for the localization of abdominal wall adhesions. Our clinical approach is that we prefer to apply the first trocar entrance in the left upper quadrant with an open method, according to CT findings. In patients who may have left upper quadrant adhesion in CT, we make the first trocar insertion with an open method in the appropriate area that is thought to be without adhesion. latrogenic bowel injury due to the first trocar insertion was not observed in any of our patients.

Studies have shown that adhesions after laparoscopic surgery are less than open surgery. ${ }^{[14,22]}$ Re-formation of adhesion after surgical treatment of post-operative adhesive disease is very important for patients with recurrent adhesions.

Successful adhesiolysis rates have been reported as 60 $100 \%$, mortality rate $0-3 \%$, and iatrogenic bowel injury rate $6.7 \%$ in the literature. ${ }^{[10,11]}$ In the study conducted by Suter et al., ${ }^{[23]}$ the rate of conversion to open surgery was reported as $43 \%$. In our study, our success rate was $84 \%$, and post-operative mortality was not observed in any of our patients. Loop ileostomy was performed in only I (5\%) of our patients due to the gastrointestinal content in the drain bag on the $3^{\text {rd }}$ post-operative day.

It has been reported that the duration of hospitalization period is shorter in laparoscopic adhesiolysis compared to open surgery. ${ }^{[13,14,24,25]}$ Saribeyoğlu et al. ${ }^{[14]}$ reported the average duration of hospital stay as 4.1 (2-7) days. In our study, the average was $4.2(2-8)$ days in accordance with the literature.

\section{CONCLUSION}

In our study, in the light of the increasing use of laparoscopic surgery in recent years, we believe that laparoscopic approach will become widespread safely due to the disadvantages of conventional surgical method in acute $\mathrm{MBO}$ due to post-operative adhesion.

Ethics Committee Approval

Approved by the local ethics committee (2020/5 I 4/I87/3). 


\section{Peer-review}

\section{Internally peer-reviewed.}

Authorship Contributions

Concept: M.M.A.; Design: S.K.; Supervision: S.K.; Fundings: M.M.A.; Materials: M.M.A.; Data: M.M.A.; Analysis: S.K.; Literature search: M.M.A., S.K.; Writing: M.M.A.; Critical revision: S.K.

\section{Conflict of Interest}

None declared.

\section{REFERENCES}

1. William A, Michael G. Intestinal Obstruction. In: George Zuidema, editor. Shackelford's surgery of the alimentary tract. Philadelphia: WB Saunders; 1996. p. 375-416.

2. van den Beukel BA, de Ree R, van Leuven S, Bakkum EA, Strik C, van Goor $\mathrm{H}$, et al. Surgical treatment of adhesion-related chronic abdominal and pelvic pain after gynaecological and general surgery: a systematic review and meta-analysis. Human Reprod Update 2017;23:276-88.

3. Perry JF Jr, Smith Ga, Yonehiro Eg. Intestinal obstruction caused by adhesion. Ann Surg 1955;142:810-6. [CrossRef]

4. Alfred SG, Charles LP. Serosal hipofibrinoliysis. Am J Surg 1973;125:80-8. [CrossRef]

5. Okabayashi K, Ashrafian H, Zacharakis E, Hasegawa H, Kitagawa Y, Athanasiou T, et al. Adhesions after abdominal surgery: a systematic review of the incidence, distribution and severity. Surg Today 2014;44:405-420. [CrossRef]

6. Yesildaglar N, Koninckx PR. Adhesion formation in intubated rabbits increases with high insufflation pressure during endoscopic surgery. Hum Reprod 2000;15:687-91. [CrossRef]

7. Luijendijk DC. Foreign materials in postoperative adhesions. Ann Surg 1996;223:242-8. [CrossRef]

8. Randall D, Joosten F, ten Broek RP, Gillott R, Bardhan KD, Strik C, et al. A novel diagnostic aid for intra-abdominal adhesion detection in cine-MR imaging: pilot study and initial diagnostic impressions. Br J Radiol 2017:20170158. [CrossRef]

9. Gerner-Rasmussen J, Donatsky AM, Bjerrum F. The role of non-invasive imaging techniques in detecting intra-abdominal adhesions: a systematic review. Langenbecks Arch Surg 2019;404:653-61. [CrossRef]

10. Nagle A, Ujiki M, Denham W, Murayama K. Laparoscopic adhesiolysis for small bowel obstruction. Am J Surg 2004;187:464-70. [CrossRef]

11. Szomstein S, Lo Menzo E, Simpfendorfer C, Zundel N, Rosenthal RJ. Laparoscopic lysis of adhesions. World J Surg 2006;30:535-40.
12. Sajid MS, Khawaja AH, Sains P, Singh KK, Baig MK. A systematic review comparing laparoscopic vs open adhesiolysis in patients with adhesional small bowel obstruction. Am J Surg 2016;212:138-50.

13. Liauw JJ, Cheah WK. Laparoscopic management of acute small bowel obstruction. Asian J Surg 2005;28:185-8. [CrossRef]

14. Saribeyoğlu K, Pekmezci S, Korman U, Kol E, Baca B, Günay S. Selective laparoscopic adhesiolysis in the management of acute and chronic recurrent adhesive bowel obstruction. Ulus Travma Acil Cerrahi Derg 2008;14:28-33.

15. Borzellino G, Tasselli S, Zerman G, Pedrazzani C, Manzoni G. Laparoscopic approach to postoperative adhesive obstruction. Surg Endosc 2004;18:686-90. [CrossRef]

16. Francois Y, Mouret P, Tomaoglu K, Vignal J. Postoperative adhesive peritoneal disease. Laparoscopic treatment. Surg Endosc 1994;8:781-3. [CrossRef]

17. Kirshtein B, Roy-Shapira A, Lantsberg L, Avinoach E, Mizrahi S. Laparoscopic management of acute small bowel obstruction. Surg Endosc 2005;19:464-7. [CrossRef]

18. Strickland P, Lourie DJ, Suddleson EA, Blitz JB, Stain SC. Is laparoscopy safe and effective for treatment of acute small-bowel obstruction? Surg Endosc 1999;13:695-8. [CrossRef]

19. Chosidow D, Johanet H, Montariol T, Kielt R, Manceau C, Marmuse $\mathrm{JP}$, et al. Laparoscopy for acute small-bowel obstruction secondary to adhesions. J Laparoendosc Adv Surg Tech A 2000;10:155-9. [CrossRef]

20. Malik E, Berg C, Meyhöfer-Malik A, Haider S, Rossmanith WG. Subjective evaluation of the therapeutic value of laparoscopic adhesiolysis: a retrospective analysis. Surg Endosc 2000;14:79-81. [CrossRef]

21. Yuvaci HU, Cevrioğlu AS, Gündüz Y, Akdemir N, Karacan A, Erkorkmaz Ü, et al. Does applied ultrasound prior to laparoscopy predict the existence of intra-abdominal adhesions? Turk J Med Sci 202;50:304-11.

22. Ziprin P, Ridgway PF, Peck DH, Darzi AW. Laparoscopic-type environment enhances mesothelial cell fibrinolytic activity in vitro via a down-regulation of plasminogen activator inhibitor- 1 activity. Surgery 2003;134:758-65. [CrossRef]

23. Suter M, Zermatten P, Halkic N, Martinet O, Bettschart V. Laparoscopic management of mechanical small bowel obstruction: are there predictors of success or failure? Surg Endosc 2000;14:478-83.

24. Hackenberg T, Mentula P, Leppäniemi A, Sallinen V. Laparoscopic versus open surgery for acute adhesive small-bowel obstruction: a propensity score-matched analysis. Scand J Surg 2017;106:28-33.

25. Sallinen V, Di Saverio S, Haukijärvi E, Juusela R, Wikström H, Koivukangas V, et al. Laparoscopic versus open adhesiolysis for adhesive small bowel obstruction (LASSO): an international, multicentre, randomised, open-label trial. Lancet Gastroenterol Hepatol 2019;4:278-86. [CrossRef] 


\section{Adezyona Bağlı Akut Mekanik Bağırsak Obstrüksiyonlarında Laparoskopik Adezyolizis}

Amaç: Ameliyat sonrası adezyona bağıı akut mekanik bağırsak obstrüksiyonunda (MBO) laparoskopik adezyolizis klinik tecrübemizi literatür ışı̆̆ı altında tartışmaktır.

Gereç ve Yöntem: Ocak 20I4-Aralık 2019 tarihleri arasında adezyona bağlı akut MBO nedeniyle laparoskopik adezyolizis uygulanan hastalar çalısmaya dahil edildi. Akut MBO tanısı, hastanın öyküsü, klinik muayene bulgusu, ayakta direkt batın grafisi (ADBG) ve bilgisayarlı tomografi (BT) ile konuldu. Hastalardan 24-48 saat sonunda konservatif tedaviye yanıt alınamayanlara laparoskopik adezyolizis uygulandı.

Bulgular: Laparoskopik adezyolizis planlanan 24 hasta çalışmaya dahil edidi. Hastaların 16'sı kadın 8'i erkek idi. Ortalama yaş 52 (27-74) idi. Hastaların 14'ünde distal ileumda, 10'unda proksimal jejunumda ameliyat sonrası adezyona bağlı MBO ve adezyonun proksimalinde dilatasyon izlendi. Hastaların dördünde (\%।6.7) teknik zorluklardan dolayı açık cerrahiye geçildi. Hastaların yedisinde olası bir kanama ve intestinal perforasyon riskini takip etmek amacıyla douglasa dren konuldu. Ameliyat sonrası birinci günde karın ağrısı ve bulantı şikayetleri gerileyen hastalarda oral alım başlandı. Hastalar ortalama ameliyat sonrası 4.2 (2-8) gün sonra taburcu edildi. Bir hastada ameliyat sonrası üçüncü günde dreninden intestinal içerik gelmesiüzerine operasyona alınarak loop ileostomi yapıldı. Hiçbir hastamızda ameliyat sonrası mortalite gözlenmedi.

Sonuç: Laparoskopik cerrahinin son yıllarda artan kullanımı ışı̆̆ında, ameliyat sonrası adezyona bağlı akut MBO'da konvansiyonel cerrahi yöntemin dezavantajlarından dolayı, laparoskopik yaklaşımın güvenle yaygınlaşacağı kanaatindeyiz.

Anahtar Sözcükler: Adezyon; laparoskopik adezyolizis; mekanik bağırsak obstrüksiyonu. 